\title{
More than the mean - A note on heterogeneity aspects in the assessment of water footprints
}

\section{Journal Article}

Author(s):

Finger, Robert (i)

Publication date:

2013-06

Permanent link:

https://doi.org/10.3929/ethz-b-000108793

Rights / license:

In Copyright - Non-Commercial Use Permitted

Originally published in:

Ecological Indicators 29, https://doi.org/10.1016/j.ecolind.2012.12.029 


\section{Postprint}

This is the accepted version of a paper published in Ecological Indicators. This paper has been peer-reviewed but does not include the final publisher proof-corrections or journal pagination.

\section{Citation for the original published paper:}

Finger, R. (2013). More than the mean - A note on heterogeneity aspects in the assessment of $\begin{array}{llll}\text { water } & \text { footprints. } & \text { Ecological } & \text { Indicators }\end{array}$ https://doi.org/10.1016/j.ecolind.2012.12.029

Access to the published version may require subscription.

N.B. When citing this work, cite the original published paper. 


\title{
More than the mean - A note on heterogeneity aspects in the assessment of water footprints
}

\begin{abstract}
Water footprints for a crop produced in a specific country are often provided as mean values. However, mean values do not account for the spatial heterogeneity of water footprints within a country that is caused by heterogeneous climate conditions and production techniques. To sufficiently inform decision makers, the underlying heterogeneity should thus also be presented. We provide an illustrate example of seed cotton production in 19 regions in Brazil and China. Even though grey water footprints in Brazil are on average smaller, it also contains the highest possible grey water footprint across all regions. To avoid misleading inference on water footprint estimates, their spatial heterogeneity should be indicated. This will enable decision makers to consider trade-offs between average values and potential extremes.
\end{abstract}

\section{Letter to the Editor}

\section{Dear Editor,}

The analysis of water footprints has emerged rapidly in the last years and contributes to an improved discussion on the implications of production and consumption decisions on water resources (see e.g., Hoekstra and Chapagain, 2008; Hoekstra and Mekonnen, 2012a,b; Liu et al., 2012; Ridoutt and Pfister, 2010a,b; Wichelns, 2011, for overviews and discussions). The ultimate goal of developing and applying ecological indicators such as water footprints should be a better information basis for any kind of decision making processes, e.g. by consumers, companies or policy makers. To this end, water footprints are often calculated on the country level to allow comparisons between, for instance, crop production in different countries (e.g. Ercin et al., 2012; Mekonnen and Hoekstra, 2012; Chapagain and Hoekstra, 2011). Based on these (single) values, conclusions and recommendations are derived, for instance, that 'water footprints are higher in one country than in another' or even that '- from a water footprint perspective - products from a specific country should be preferred'. We think, however, that more than country average values are required as a solid basis for decision making. 
This is due to the fact that crop production within a country usually takes place in different regions which often face different climatic and soil conditions, leading to heterogeneous levels of crop water requirements and (effective) water availability. Furthermore, production techniques can be heterogeneous across regions, e.g. with regard to the use of irrigation. As a result, also water footprints may be heterogeneous within a country. To derive a single water footprint for a country, regional estimates are usually combined using weighted averages, with relative production areas of regions being used as weights (e.g. Chapagain et al., 2006; Chapagain and Hoekstra, 2011). This, however, clearly removes information on the underlying heterogeneities of water footprints. To avoid this non-consideration of interesting information, some authors present regional specific estimates or present water footprints separately for different technologies (e.g. rainfed and irrigated) (e.g. Ercin et al., 2012; Aldaya and Hoekstra, 2010, Pfister et al., 2011). Such a high level of disaggregation in the presentation of results is, however, usually not possible for larger analysis involving several crops and countries. To overcome this drawback, country level water footprint estimates should be accompanied by additional information on the dispersion of water footprints within a country.

This is relevant because decision making processes, in particular with respect to environmental impacts, are not exclusively focused on average conditions. Rather, decision makers will tend to avoid potential extreme environmental harms. Often, environmental attributes of a product cannot be assessed with certainty. For instance, the exact water footprint of a product/production process is not known by all actors in the value chain (e.g. if only the country of origin is indicated). Thus, the 'environmental soundness' of a product may be a 'credence good' for these actors (Kirchhoff, 2000) ${ }^{1}$. However, there is the possibility that the environmental impacts associated with a specific product may be revealed. In the case of water footprints this may happen, for example, if catastrophic situations of water bodies are associated with high local or regional grey and/or blue water footprints of a certain product. The direct link between such environmental disaster and a specific product will negatively influence consumers' buying decisions, because these are particularly sensitive to bad environmental associations (e.g. Borin et al., 2011). Taking such considerations into account, actors in agricultural value chains are likely to reduce these risks if making buying decisions. Thus, involved actors may tend to over-comply with usual standards (Kirchhoff, 2000), in our example by reducing potential environmental harms in presence of the risk that negative

\footnotetext{
${ }^{1}$ We are aware that water footprints itself may not be directly connectable with observed environmental impacts (Wichelns, 2011), and that such impacts are usually non-linear and involve threshold effects. However, we assume that at least the probability for environmental damages is correlated with water footprints.
} 
environmental impacts can be revealed (see Lambooy, 2010, for further discussions on firms motivations to reduce water footprints) ${ }^{2}$.

Along these lines, the average water footprint of a product for a specific country may not be informative enough. Even though the water footprint of a product from a specific country may have - on average - smaller values, this product may not be preferred if the buying decision could imply a very high water footprint associated with a higher risk for environmental harms in a certain region of this country. For this purpose, mean values of water footprints may not be sufficient. Furthermore, research conclusions like 'products from a specific country should be preferred from a water footprint perspective' based on comparisons of average water footprints could be misleading in this context of decision making.

To illustrate our concerns with average values reported at the country level, we use the example of water footprints from seed cotton production in Brazil and China. Grey, green and blue water footprints (in $\mathrm{m}^{3} / \mathrm{ton}$ ) for the major production regions in these countries (following Chapagain et al., 2006) are taken from Hoekstra and Mekonnen (2010). These values are presented in Table 1 and 2 together with regional shares to the national harvesting area (taken from Chapagain et al., 2006).

\footnotetext{
${ }^{2}$ With regard to direct communication to consumers, a more complex reporting of water footprint also increases the risk of confusing - and a balance between complexity and communication has to be found (Tukker et al., 2010).
} 
Table 1. Water footprints for seed cotton production in China in $\mathrm{m}^{3} /$ ton

\begin{tabular}{|c|c|c|c|c|c|c|c|c|c|c|c|c|c|c|c|}
\hline Province & Xinjiang & Henan & Jiangsu & Hubei & Shandong & Hebei & Anhui & Hunan & Jiangxi & Sichuan & Shanxi & Zhejiang & \multicolumn{3}{|c|}{ Country Level } \\
\hline Share* & $21.5 \%$ & $16.6 \%$ & $11.5 \%$ & $11.4 \%$ & $10 \%$ & $6.7 \%$ & $6.4 \%$ & $5.2 \%$ & $3.3 \%$ & $2.3 \%$ & $1.7 \%$ & $1.3 \%$ & $\begin{array}{l}\text { Weighted } \\
\text { Mean }\end{array}$ & $\begin{array}{l}\text { Weighted } \\
\text { Median }\end{array}$ & Range \\
\hline Grey WFP & 995 & 594 & 589 & 588 & 599 & 611 & 589 & 589 & 596 & 588 & 608 & 591 & 628 & 593 & $\begin{array}{l}588- \\
995\end{array}$ \\
\hline Green WFP & 979 & 1522 & 1788 & 1307 & 1404 & 1241 & 1751 & 1283 & 1703 & 1096 & 1317 & 1807 & 1377 & 1361 & $\begin{array}{l}979- \\
1807\end{array}$ \\
\hline Blue WFP & 952 & 143 & 46 & 5 & 445 & 617 & 21 & 7 & 16 & 16 & 300 & 19 & 335 & 95 & $5-952$ \\
\hline
\end{tabular}

* Share to total harvesting area. Data is taken from Hoekstra and Mekonnen (2010).

Table 2. Water footprints for seed cotton production in Brazil in $\mathrm{m}^{3} / \mathrm{ton}$

\begin{tabular}{|c|c|c|c|c|c|c|c|c|c|c|}
\hline State & Parana & S. Paulo & Bahia & M. Gerais & M. Grosso & Goias & M. Grosso & \multicolumn{3}{|c|}{ Country Level } \\
\hline Share* & $43 \%$ & $21 \%$ & $8 \%$ & $5 \%$ & $5 \%$ & $4 \%$ & $4 \%$ & Weighted Mean & $\begin{array}{l}\text { Weighted } \\
\text { Median }\end{array}$ & Range \\
\hline Grey WFP & 497 & 471 & 1154 & 471 & 470 & 470 & 479 & 544 & 488 & $470-1154$ \\
\hline Green WFP & 2714 & 2362 & 1514 & 2219 & 2223 & 2188 & 2596 & 2442 & 2479 & $1514-2714$ \\
\hline
\end{tabular}

* Share to total harvesting area. Data is taken from Hoekstra and Mekonnen (2010). 
Grey water footprints in Brazilian states are usually smaller than Chinese cotton producing provinces (Tables 1 and 2). Accordingly, the weighted average grey water footprint of Brazilian seed cotton is, with $544 \mathrm{~m}^{3} /$ ton, smaller than for China $\left(628 \mathrm{~m}^{3} / \mathrm{ton}\right)$. However, because of high grey water footprints in the State of Bahia $\left(1154 \mathrm{~m}^{3} /\right.$ ton $)$, seed cotton from Brazil can also imply the highest possible grey water footprint among the here presented choices. Thus, even though it represents higher average grey water footprints decision makers may opt for seed cotton from China in order to avoid risks of large environmental impacts. To allow decision makers to explore these trade-offs based on their own preferences, the within-country dispersion of water footprints should be provided. Pfister et al. (2011), for instance, provide production-weighted coefficients of variation of water footprints for each country.

The potential loss of information by providing only mean values is also underlined if comparing blue water footprints in our example (Tables 1 and 2). Seed cotton production in China is associated with high blue water footprints (the weighted mean is $335 \mathrm{~m}^{3} /$ ton), while Brazil has virtually no blue water footprint on the country level (with a weighted mean of $27 \mathrm{~m}^{3} /$ ton). However, for some Chinese provinces the blue water footprints of seed cotton production is zero (where water provision from rainfall is sufficient), while substantial irrigation is required (leading to high blue water footprints) in one state of Brazil (Bahia). Again, comparisons of water footprints may not be as clear-cut as suggested by comparisons of mean values. Making information on heterogeneity behind the data available is necessary to provide a sufficient information basis for decision makers.

The need for more careful presentation of water footprints could be also valid if the level of investigation is disaggregated further than in our example. Water footprints may vary not only across but also within regions (e.g. Pfister et al., 2011). This can imply an even higher range of water footprints at sub-regional levels. Despite this fact, we have chosen to present our example at the state (Brazil) and province (China) level. This choice was motivated by the fact that this disaggregation to state and province levels accounts for different climate zones within a country, which is an important determinant for heterogeneities in water footprints. Nevertheless, we are aware that the here presented conclusion that cotton production in Brazil may imply higher water footprints than in China may not necessarily hold if comparisons are made at sub-regional levels. Along these lines, further research is required to ensure that comparisons are made at the correct levels. The here reported aggregation problems may also imply that water footprints should be preferably assessed and reported at local levels (Pfister et 
al., 2011). In addition, especially local estimates of water footprints can support policy makers to identify and tailor necessary policy interventions.

In addition to addressing spatial heterogeneities explicitly in water footprint assessment, also the variability of these indicators over time should be taken into account in future research. Climatic variables that are used to calculate water footprints and trigger important management practices such as irrigation (e.g. rainfall, temperature, evapotranspiration) usually differ across years. Thus, also annual water footprints may vary substantially over time. This (temporal) heterogeneity is not reflected in average values derived from observations over a certain time period, but should be provided. Besides being informative for decision makers, information on spatial and temporal heterogeneity can be used to derive statistical inference on water footprints in future research.

\section{Acknowledgment}

I would like to thank tow anonymous reviewers and Nadja El Benni for helpful comments and suggestions based on an earlier draft. 


\section{References}

Aldaya, M.M., Hoekstra, A.Y., 2010. The water needed for Italians to eat pasta and pizza. Agric. Syst. 103, 351-360.

Borin, N., Cerf, D. C., Krishnan, R., 2011. Consumer effects of environmental impact in product labelling. J. Cons. Marketing 28, 76-86.

Chapagain, A.K., Hoekstra, A.Y., 2011. The blue, green and grey water footprint of rice from production and consumption perspectives. Ecol. Econ. 70, 749-758.

Chapagain, A.K., Hoekstra, A.Y., Savenije, H.H.G., Gautam, R. 2006. The water footprint of cotton consumption: An assessment of the impact of worldwide consumption of cotton products on the water resources in the cotton producing countries. Ecol. Econ. 60, 186-203

Ercin, A.E., Aldaya, M.M., Hoekstra, A.Y., 2012. The water footprint of soy milk and soy burger and equivalent animal products. Ecol. Indic. 18, 392-402.

Hoekstra, A.Y., Chapagain, A.K., 2008. Globalization of water: Sharing the planet's freshwater resources. Blackwell Publishing, Oxford, UK.

Hoekstra, A.Y., Mekonnen, M.M. 2010. The green, blue and grey water Footprint of crops and derived crop products, Volume 1: Main Report. Value of Water Research Report Series No. 48. UNESCOIHE, Delft.

Hoekstra, A.Y., Mekonnen, M.M., 2012a. The water footprint of humanity. P. Natl. A. Sci., doi/10.1073/pnas.1109936109.

Hoekstra, A.Y., Mekonnen, M.M., 2012b. From water footprint assessment to policy. P. Natl. A. Sci. 109, E1425.

Kirchhoff, S., 2000. Green Business and Blue Angels. Environ. Resour. Econ. 15, 403-420.

Lambooy, T. 2011. Corporate social responsibility: sustainable water use. J. Clean. Prod. 19, 852-866.

Liu, C., Kroeze, C., Hoekstra, A.Y., Gerbens-Leenes, W. 2012. Past and future trends in grey water footprints of anthropogenic nitrogen and phosphorus inputs to major world rivers. Ecol. Indic. 18, 42-49.

Mekonnen, M.M., Hoekstra, A.Y., 2012. A global assessment of the water footprint of farm animal products. Ecosystems 15, 401-415.

Pfister, S., Bayer, P., Koehler, A., Hellweg, S.., 2011. Environmental impacts of water use in global crop production: hotspots and trade-offs with land use. Environ. Sci. Techn. 45, 57615768.

Ridoutt, B.G., Pfister, S. 2010a. A revised approach to water footprinting to make transparent the impacts of consumption and production on global freshwater scarcity. Glob. Environ. Change 20, 113-120.

Ridoutt, B.G., Pfister, S. 2010b. Reducing humanity's waterfootprint. Environ. Sci. Technol. 44, 6019-6021

Tukker, A., Cohen, M.J., Hubacek, K., Mont, O., 2010. The impacts of household consumption and options for change. J. Indust. Ecol. 14, 13-30.

Wichelns, D., 2011. Do the Virtual Water and Water Footprint Perspectives Enhance Policy Discussions? Int. J. Water Resour. D. 27, 633-645. 